\title{
PENDEKATAN SAINS TEKNOLOGI MASYARAKAT (STM) DALAM PEMBELAJARAN
}

\author{
Roni Faslah*
}

\begin{abstract}
Influences of globalization are getting felt together with the increasing of variety kinds of information providers in the form of press released or unreleased, broadcast or not broadcast, electronic or not electronic information providers, such as, newspaper, magazine, radio television, facsimiles, computer, internet, communication satellite. Improvement of technology of communication and information inclined to influence the condition of social aspect, economic aspect, culture, and also the condition of education. The applications of communication and information are giving the possibility to create global learning condition which is connected to the link that put students in the central of learning process and surrounded by many kinds of electronic learning source. Base on all of that, conventional education should be softer by accepting new style of learning which is completed by improved technology. We really need human beings, who can get along with the improvement of technology, who have knowledge of tools, source and process where knowledge is put as the central of the soul, comprehended and used in their live to increase the quality of work in the purpose of getting better prosperity in their life. The elements of human which are improved in the aspect of technology are power of thinking, power of heart, and physical power.
\end{abstract}

Keywords: globalization, learning, communication and information technology

\section{PENDAHULUAN}

informasi beberapa tahun

Roni Faslah, S.Pd., MM. adalah dosen Fakultas Ekonomi Universitas Negeri Jakarta belakangan ini berkembang dengan kecepatan yang sangat tinggi, sehingga dengan perkembangan ini telah mengubah paradigma masyarakat dalam mencari dan mendapatkan informasi, yang tidak 
lagi terbatas pada informasi surat kabar, audio visual dan elektronik, tetapi juga sumber-sumber informasi lainnya yang salah satu diantaranya melalui jaringan Internet.

Perkembangan teknologi informasi dan komunikasi pada era globalisasi tampaknya membawa perubahan pada setiap aspek kehidupan masyarakat. Perubahan itu telah membawa pergeseran nilainilai dalam masyarakat. Perubahan bersifat positif juga meningkatkan peradaban masyarakat. Di sisi lain perubahan bersifat negatif telah merusak sendi-sendi kehidupan masyarakat. Fenomena pada masyarakat dewasa ini, telah terjadinya proses perubahan sangat cepat, terkait dengan pekembangan ilmu pengetahuan dan teknologi. Karena perubahan sangat pesat pada masyarakat, akibatnya manusia akan berhadapan dengan suatu penyakit baru, ditandai oleh suatu krisis (Sudibya, 1994:70) penyakit baru dimaksud adalah merosotnya nilai-nilai keagamaan.

\section{Data dan Fakta}

Teguh Dalyono (2009) dalam penelitiannya menemukan bahwa hanya 46\% mahasiswa (Yogyakarta) menggunakan alat elektronik mereka untuk ilmu pengetahuan. Data Direktorat Jenderal Pendidikan Tinggi -dalam Pannen (2005)menunjukkan bahwa kesadaran dalam pemanfaatan TI dalam proses pembelajaran masih sangat rendah. Analisis terhadap proposal teaching grant, baru 29,69\% yang memanfatkan media berbasis teknologi komputer. Ketersedian media berbasis teknologi informasi juga masih terbatas. Hanya 15,54\% perguruan tinggi negeri (PTN) dan $16,09 \%$ perguruan tinggi swasta (PTS) yang memiliki ketersediaan media berbasis teknologi informasi. Sekitar 16,65\% mahasiswa dan $14,59 \%$ dosen yang mempunyai akses terhadap teknologi informasi. Hasil survei yang melihat pemanfaatan TI pada tahun 2004 menunjukkan bahwa baru 17,01\% PTN, 15,44\% PTS, 9,65\% dosen, dan $16,17 \%$ mahasiswa yang memanfaatkan TI dengan baik. Secara keseluruhan statistik ini menunjukkan bahwa adopsi TI dalam dunia pendidikan di Indonesia masih rendah.

PBB melalui UNCTAD membuat indeks pengembangan teknologi informasi dan komunikasi yang diukur berdasarkan 4 dimensi yaitu keterhubungan (connectivity), akses (access), kebijakan (policy), 
dan penggunaan (diffusion). Indonesia berada pada urutan ke-77 dari 171 negara, atau masih dibawah Singapura yang menempati urutan 14, Malaysia urutan ke-43, dan Filipina urutan ke-59; tetapi masih lebih tinggi dibandingkan Thailand pada urutan ke-92 dan Vietnam urutan ke-113 (UNCTAD, 2003).

Indikator

tersebut menunjukkan bahwa pemanfaatan teknologi informasi dan komunikasi di Indonesia masih tertinggal dibandingkan negara-negara lain. International Communication Union (ITU) melaporkan profil pamanfaatan information and communication technology (ICT) di Indonesia, yaitu jumlah komputer pribadi sebanyak 3.022 .000 unit atau 1,36 per 100 penduduk, pengguna internet sebanyak 14,5 juta orang atau 6,52 per 100 penduduk, dan jumlah internet host sebanyak 111.630 atau 5,01 per 10.000 penduduk. Statistik tersebut masih di bawah rata-rata dunia dan Asia yang tercatat sebesar 12,82 dan 6,27 untuk komputer, 13,70 dan 8,18 untuk pengguna internet, dan 417,91 dan 75,08 untuk internet host (ITU, 2004).

Fakta lainnya adalah Networked Readiness Index (NRI) yang dikembangkan oleh Center for International Development (CID) di Harvard University. NRI didefinisikan sebagai derajat sebuah komunitas siap untuk berpartisipasi dalam dunia terhubung jaringan (networked world). Nilai NRI Indonesia adalah 3.24 dan menempati urutan ke-59 dari 75 negara yang disurvey.

Berbagai indikator tersebut menunjukkan bahwa Indonesia pada saat ini masih relatif tertinggal dalam percaturan ekonomi dunia yang sudah mengarah ke era globalisasi dan perdagangan bebas. Dan di era tersebut, penguasaan teknologi informasi dan komunikasi menjadi faktor yang sangat penting. Sedangkan penguasaan jenis teknologi tersebut erat kaitannya dengan pengembangan sumber daya manusia sebagai aktor utama dalam implementasinya. Celakanya, Indeks Pengembangan SDM Indonesia pada tahun 2003 berada di posisi 110 dari 177 negara.

\section{Ketertinggalan dalam} berbagai indikator tersebut ternyata berhubungan dengan ketertinggalan indikator makro ekonomi sebuah negara. Negara-negara yang tingkat penggunaan TIK relatif tinggi secara umum mempunyai pendapatan per kapita yang tinggi. Pola 
kecenderungannya dapat dilihat pada gambar di bawah ini.

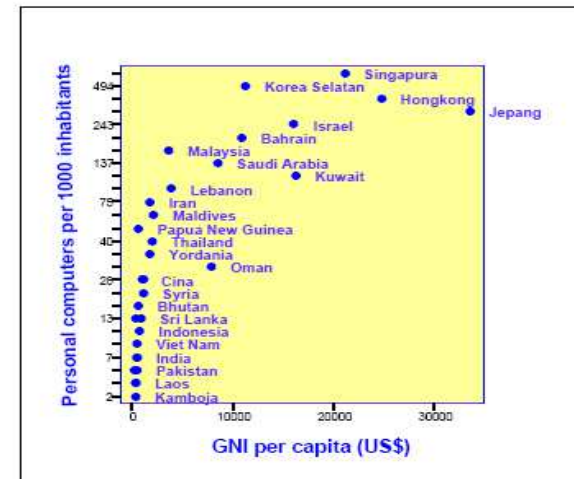

Populasi PC dan pendapatan per kapita

Laporan UNDP (2004) menunjukkan adanya pola hubungan antara berbagai indikator TIK dengan indikator yang terkait dengan pendapatan dan indeks pengembangan SDM semakin meningkat pada abad 21 ini. Peningkatan hubungan yang sangat menarik terjadi antara penggunaan komputer pribadi (PC) dengan

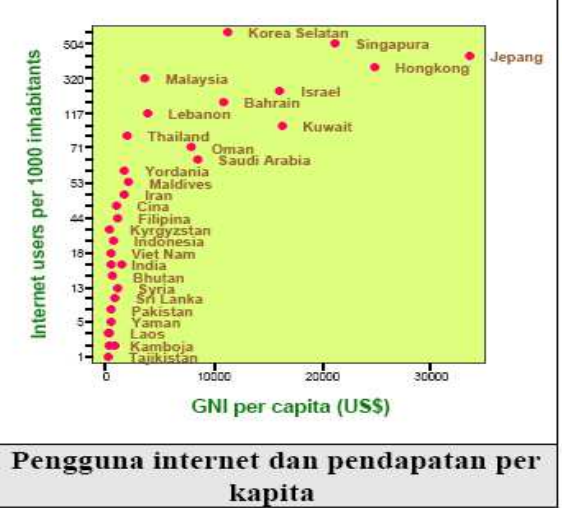

pendapatan per kapita dan indeks pengembangan SDM. Indeks pengembangan SDM untuk Negaranegara berkembang cenderung meningkat dari tahun 1975 sampai 2001. Bagaimana posisi Indonesia dibandingkan dengan negaranegara Asia lainnya dapat dilihat pada gambar berikut.

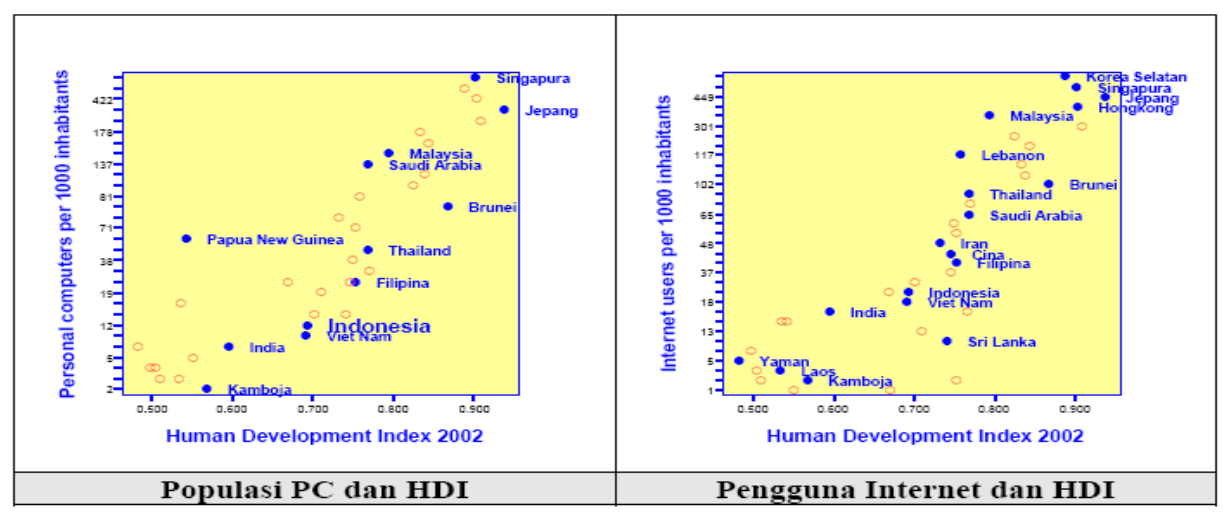

Berbagai ukuran inovasi pengembangan merupakan salah tersebut menunjukkan bahwa satu ukuran inovasi yang perlu kekayaan intelektual, goodwill, dan mendapatkan perhatian serius. kegiatan penelitian dan Indikator ini berkaitan erat dengan 
penguasaan sumber daya manusia terhadap ilmu pengetahuan dan teknologi (IPTEK).

\section{Globalisasi Pendidikan}

Sedikitnya ada tiga hal dari buku yang ditulis John Miklethwait dan Adrian Wooldridge (2000) yang patut dicermati dalam kaitannya dengan dunia pendidikan: (1) terkait dengan nilai-nilai yang dibawa oleh globalisasi: ... even as it dispenses freedoms, it imposes responsibilities: (2) terkait dengan pemyataan mereka: "Education is still a surprisingly parochial affair", dan (3) "The lack of a core curriculum encourages a shoppingmall approach to education". Pernyataan pertama terkait dengan nilai-nilai kemerdekaan dan tanggung jawab. Pernyataan kedua terkait dengan penyelenggaraan sistem pendidikan. Pernyataan ketiga terkait dengan pendekatan pembelajaran yang lebih bersifat shopping-mall karena kurikulum inti yang dikembangkan sangat kurang. Didalam menyongsong masa depan pada umumnya orang sependapat bahwa tidak ada sesuatu yang pasti. Para ahli dapat saja membuat berbagai ramalan atau prediksi, tetapi akurasi dari prediksi atau ramalan tersebut tidak dijamin.
Dalam keadaan yang sedemikian, sesuatu yang pasti adalah perubahan atau change itu sendiri. Perubahan terjadi secara terusmenerus dalam skala dan intensitas yang semakin meningkat. Khususnya dalam dua tiga dekade terakhir ini, perubahan tersebut telah terjadi dalam skala dan intensitas yang sangat tinggi.

Pendorong utama dari perubahan ini adalah perkembangan ilmu pengetahuan dan teknologi, khususnya perkembangan teknologi informasi dan komunikasi. Kemajuan yang sangat pesat dalam pemahaman kita tentang dunia diterapkan dan dikembangkan secara cepat dan meluas dalam berbagai bidang seperti industri, pertanian, kedokteran dan jasa. Berbeda dengan masa sebelumnya, tingkat kecepatan yang membawa perubahan ini, menembus batasbatas nasional dan regional. Dengan demikian, ilmu pengetahuan, teknologi dan pengetahuan manajerial cepat menyebar, sehingga menambah jumlah bangsa yang memiliki kemampuan teknis untuk berproduksi dan kemampuan rekayasa. Hal ini lebih dimungkinkan lagi oleh kemampuan dan kecepatan komunikasi, misalnya dalam bidang transportasi, satelit dan jaringan 
komputer. Oleh karena itu, cakupan dari berbagai kegiatan produksi termasuk penelitian, rekayasa, produksi dan pemasaran dalam banyak sektor industri telah berkembang menjadi global. Dengan demikian, kemampuan teknologi jauh lebih menyebar di kalangan negara-negara industri maupun di negara-negara yang sedang mengalami proses industrialisasi. Hal ini sekaligus mengakhiri peranan tunggal Amerika Serikat dalam bidang ilmu pengetahuan dan teknologi. Keunggulan teknologi dan industri Amerika Serikat sampai dengan permulaan dekade 1970-an menyebabkan arus teknologi berlangsung satu arah yakni dari Amerika Serikat ke negara lain di dunia. Akan tetapi sejak pertengahan dekade 1970-an pola tersebut telah berubah menjadi pola murti arah. Sejalan dengan hal tersebut, telah terjadi pula perubahan pesat di bidang sosial budaya masyarakat. Kriteria rnengenai pembangunan sosial yang sebelumnya bersifat lokal berkembang menjadi kriteria yang bersifat global.

Pendidikan merupakan faktor utama yang menggerakkan perubahan tersebut terjadi. Dalam bidang pendidikan ukuran mengenai perkembangannya mengikuti standar internasional. Pembaharuan dalam bidang pendidikan merupakan suatu karakter dunia modern. Khususnya kurikulum pendidikan, seyogyanya dirancang untuk memberikan pengalaman yang merangsang peningkatan kreativrtas, intelektualitas, dan daya analisis. Kurikulum harus menyajikan hal-hal yang praktis dan disesuaikan dengan latar belakang kehidupan yang bervariasi, tujuan hidup yang berbeda, serta daya pemahaman terhadap persoalan yang berbeda pula. Pendidikan harus dapat menyajikan kesempatan-kesempatan untuk berbuat dan bertindak berdasarkan apa yang dipahami seseorang maupun kesempatan untuk berteori tentang solusi yang ideal dari berbagai masalah. Dengan singkat, kurikulum harus dapat diperkenalkan kepada anak didik dengan berbagai cara belaj'ar maupun berbagai jenis pengetahuan. Pada gilirannya halhal ini mampu mempersiapkan anak didik untuk merencanakan masa depannya dan masyarakatnya, serta berperan aktif dalam merealisasikannya. 


\section{Pendekatan Sains Teknologi Masyarakat (STM)}

Istilah Sains Teknologi Masyarakat (STM) dalam bahasa Inggris disebut Sains Technology Society (STS), Science Technology Society and Environtment (STSE) atau Sains Teknologi Lingkungan dan Masyarakat. Meskipun istilahnya banyak namun sebenarnya intinya sama yaitu Environtment, yang dalam berbagai kegiatan perlu ditonjolkan.

Sains Teknologi Masyarakat (STM) merupakan pendekatan terpadu antara sains, teknologi, dan isu yang ada di masyarakat. Adapun tujuan dari pendekatan STM ini adalah menghasilkan peserta didik yang cukup memiliki bekal pengetahuan, sehingga mampu mengambil keputusan penting tentang masalah-masalah dalam masyarakat serta mengambil tindakan sehubungan dengan keputusan yang telah diambilnya.

Keterpaduan dalam sains terdiri dari beberapa pola, antara lain keterpaduan proses dan produk, keterpaduan berbasis obyek, keterpaduan antar bidang, dan keterpaduan berbasis persoalan. Bagi siswa Sekolah Dasar di kelas tinggi memiliki kecenderungan pada keterpaduan berbasis persoalan, karena sistem pembelajarannya sudah menggunakan guru bidang studi. Siswa di kelas rendah mengikuti pola keterpaduan antar bidang, karena masih mengunakan sistem guru kelas.

Melalui proses pembelajaran dengan menggunakan pendekatan STM akan mengantarkan siswa untuk bisa melihat ilmu sebagai dunianya. STM berusaha menjembatani antara ilmu dan masyarakat, sehingga ilmu yang diperoleh di bangku sekolah akan sangat terasa manfaatnya apabila diterapkan dalam masyarakat.

Menurut Yager, secara umum pembelajaran dengan menggunakan pendekatan STM memiliki karakteristik sebagai berikut:

1. Identifikasi masalah-masalah setempat yang memiliki kepentingan dan dampak

2. Penggunaan sumber daya setempat (manusia, benda, lingkungan) untuk mencari informasi yang dapat digunakan dalam memecahkan masalah

3. Keterlibatan siswa secara aktif dalam mencari informasi yang dapat diterapkan untuk memecahkan masalah-masalah dalam kehidupan sehari-hari

4. Penekanan pada ketrampilan proses 
5. Kesempatan bagi siswa untuk berperan sebagai warga negara dimana ia mencoba untuk memecahkan masalah-masalah yang telah diidentifikasi

6. Identifikasi bagaimana sains dan teknologi berdampak pada masyarakat di masa depan

7. Kebebasan atau otonomi dalam proses belajar

Pembelajaran

dengan

menggunakan pendekatan STM dilandasi oleh dua hal penting, yaitu: (1) adanya keterkaitan yang erat antara sains, teknologi, dan masyarakat yang dalam pembelajarannya menganut pandangan konstruktivisme, yang menekankan bahwa si pembelajar membentuk atau membangun pengetahuannya melalui interaksinya dengan lingkungan; (2) dalam pembelajaran terkandung lima ranah, yaitu pengetahuan, sikap, proses, kreativitas, dan aplikasi..

\section{William H. Cartwright} menyatakan bahwa ilmu alam dan ilmu sosial mempunyai kaitan erat dan tidak dapat dipisahkan. Dampak ilmu alam yang dirasakan oleh masyarakat merupakan fenomena sosial. Sebagai contoh, pengaruh kemajuan ilmu dan teknologi, pertanian, kesehatan, dan perang juga berpengaruh terhadap masyarakat. Masuknya teknologi dalam masyarakat tidak hanya mengubah kondisi kehidupan masyarakat, tetapi juga merubah cara atau gaya hidup masyarakat. Pemikiran ilmiah akan berpengaruh terhadap alam yang merupakan tempat tinggal bagi masyarakat. Kenyataan itu menyadarkan kita bahwa memang ada kaitan erat antara ilmu alam dengan ilmu pengetahuan sosial.

Dengan demikian antara sains, teknologi, dan masyarakat terdapat hubungan yang saling mempengaruhi. Sains dan teknologi dihasilkan oleh dan untuk masyarakat, perkembangan sains dan teknologi ditentukan oleh dinamika kehidupan masyarakat, sebaliknya kehidupan masyarakat dipengaruhi oleh perkembangan sains dan teknologi.

Kemajuan sains dan teknologi seringkali berdampak pada terjadinya masalah-masalah dalam masyarakat. Hal ini disebabkan karena kemajuan sains dan teknologi sering tidak diiringi kesiapan dari masyarakat termasuk peserta didik. Misalnya, berbagai siaran Televisi akan menimbulkan masalah bagi anak didik seperti, malas belajar, meniru hal-hal negatif 
dari adegan film, kekerasan, dan sebagainya.

Peran ilmu sosial dalam menghadapi kemajuan sains dan teknologi lebih mengutamakan pola berpikir bagaimana menghadapi dampak sosial akibat dari perkembangan dan penerapan sains dan teknologi. Hal ini diperlukan agar masyarakat tetap dapat menerima berbagai perkembangan sains dan teknologi disertai dengan pemahaman yang cukup. Dengan demikian masyarakat dapat menerima hasil kemajuan teknologi tanpa disertai gejolak-gejolak sosial, bahkan teknologi justru dapat digunakan untuk kemajuan masyarakat itu sendiri.

\section{Pengembangan}

Manusia

\section{Berkarakter Teknologi}

Proses pengembangan manusia berkarakter teknologi dilakukan melalui tahap kesadaran, penjajagan, orientasi, dan penyiapan. Pengembangan manusia berkarakter teknologi ditempuh secara serentak dan komplemen melalui jalur keluarga, sekolah, dan masyarakat. Pendidikan teknologi dasar agar diterapkan sedini mungkin di Sekolah Dasar, Sekolah Lanjutan Tingkat Pertama, dan Sekolah Menengah Umum untuk pengembangan

selanjutnya.

Demikian pula kemajuan bidang teknologi informasi (internet) memberi tantangan pada dunia pendidikan, khususnya dalam proses belajar mengajar, yaitu dijadikannya internet sebagai media dalam model pembelajaran. Secara teoritik, internet layak dijadikan bagian dari sistem multimedia dalam pembelajaran. Dengan demikiar internet sebagai media baru, merupakan terobosan yang perlu dipertimbangkan untuk membangun manusia berkarakter teknologi dan jauh berwawasan kedepan.

Ada beberapa peran bagi pendidik dalam rangka pemanfaatan teknologi informasi di sekolah. Menurut Lee Kar Tin (2001) peranperan tersebut seperti dipaparkan berikut ini.

1) Pertama, ada sejumlah pendidik yang mengaku bahwa mereka belum memiliki kemampuan untuk menggunakan alat teknologi informasi. Ada pendidik, yang sama sekali tidak memiliki pengetahuan untuk menggunakan komputer. Ada pula pendidik yang sudah memiliki pengetahuan menggunakan komputer, tetapi belum nemiliki kemampuan untuk menggunakan internet. 
Dalam hal ini, perlu ada penekanan kepada para pendidik, agar mereka memiliki kemampuan untuk menggunakan teknologi informasi.

2) Kedua, pendidik dapat mengikutsertakan keunggulan teknologi informasi dalam pemberian tugas kepada para peserta didik. Peserta didi ditugaskan untuk memanfaatkan keunggulan teknologi informasi, sehingga mereka dapat menghasilkan pekerjaan yang sempurna. Pendidik, misalnya, menugaskan peserta didik untuk mengarang atau melukis dengan menggunakan komputer. Dengan fasilitas edit yang canggih, pendidik dapat menuntut karya peserta didik yang terus diedit sampai sempurna.

3) Ketiga, dibawah pengawasannya secara langsung, pendidik dapat menugaskan para peserta didik untuk bermain di komputer sesaat sebelum pelajaran dimulai, berkenaan dengan topik yang akan diajarkan. Sebelum masuk kelas, pendidik misalnya, dapat menugaskan peserta didik untuk bermain dengan komputer, untuk membuat bermacam lingkaran serta bermacam susunan dari sejumlah lingkaran. Setelah itu, pendidik memberi pelajaran tentang lingkaran.

4) Keempat, pendidik dapat menugaskan para peserta didik untuk mengumpulkan sejurnlah informasi tertentu dari internet serta menyusun laporan tertulis tentang kumpulan informasi itu. Lebih baik lagi, kalau pendidik tertebih dahulu mengakses informasi itu, sehingga peserta didik ditugasi untuk mengakses informasi yang telah diakses oleh pendidik itu. Dalam rangka ini, pendidik dapat juga menugaskan para peserta didik untuk mencari sejumlah judul literatur perpustakaan melalui internet pada website tertentu. Misalnya, pendidik memberikan nama pengarang, peserta didik mencari judul literatur atau sebaliknya.

5) Kelima, sejumlah kegiatan pembelajaran yang biasanya dilakukan melalui transparansi, slide, film atau videotape, kini sudah dapat dilakukan melalui teknologi informasi yakni komputer; bahkan pekerjaan rumah dapat juga dikerjakan melalui teknologi informasi. 
Disamping berbagai kemungkinan ini, pendidik dapat saja secara proaktif mencari kegiatan pembelajaran lainnya yang dapat memanfaatkan keunggulan teknologi informasi. Kegiatan pembelajaran yang dimaksud, termasuk didalamnya latihan berpikir sistematik melalui pembuatan program komputer seperti yang telah banyak dilakukan di sekolah sekarang ini.

\section{Memodernisasi Pendidikan \\ Melalui Teknologi Informasi (TI)}

Menurut Resnick (2002) ada tiga hal penting yang harus dipikirkan ulang terkait dengan modernisasi pendidikan: bagaimana kita belajar (how people learn); (2) apa yang kita pelajari (what people learn); dan (3) kapan dan di mana kita belajar (where and when people learn). Dengan mencermati jawaban atas ketiga pertanyaan ini, dan potensi TI yang bisa dimanfaatkan seperti telah diuraikan sebelumnya, maka peran TI dalam moderninasi pendidikan bangsa dapat dirumuskan. Hubungan antara TI dan reformasi pendidikan secara grafis diilustrasikan pada Gambar 1.

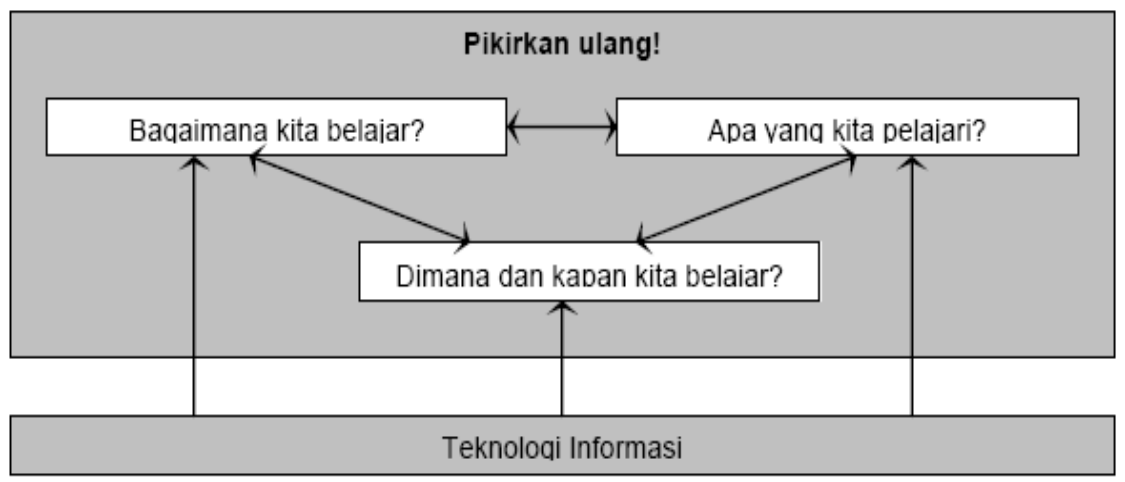

\section{Pertanyaan pertama,} bagaimana kita belajar, terkait dengan metode atau model pembelajaran. Cara berinteraksi antara guru dengan siswa3 sangat menentukan model pembelajaran. Terkait dengan ini, menurut Pannen
(2005), saat ini terjadi perubahan paradigma pembelajaran terkait dengan ketergantungan terhadap guru dan peran guru dalam proses pembelajaran. Proses pembelajaran seharusnya tidak $100 \%$ bergantung kepada guru lagi (instructor 
dependent) tetapi lebih banyak terpusat kepada siswa (studentcentered learning atau instructor independent). Guru juga tidak lagi dijadikan satu-satunya rujukan semua pengetahuan tetapi lebih sebagai fasilitator atau konsultan (Resnick, 2002).

Intervensi yang bisa dilakukan TI dalam model pembelajaran ini sangat jelas. Hadirnya e-learning dengan semua variasi tingkatannya telah memfasilitasi perubahan ini. Secara umum, e-learning dapat didefinisikan sebagai pembelajaran yang disampaikan melalui semua media elektronik termasuk, Internet, intranet, extranet, satelit, audio/video tape, TV interaktif, dan CD ROM (Govindasamy, 2002). Menurut Kirkpatrick (2001), elearning telah mendorong demokratisasi pengajaran dan proses pembelajaran dengan memberikan kendali yang lebih besar dalam pembelajaran kepada siswa.

Secara umum, intervensi $e$ learning dalam proses pembelajaran dapat dikelompokkan menjadi dua: komplementer dan substitusi. Yang pertama mengandaikan bahwa cara pembelajaran dengan pertemuan tatap-muka masih berjalan tetapi ditambah dengan model interaksi berbantuan $\mathrm{TI}$, sedang yang kedua sebagian besar proses pembelajaran dilakukan berbantuan TI. Saat ini, regulasi yang dikeluarkan oleh pemerintah juga telah memfasilitasi pemanfaatan e-learning sebagai substitusi proses pembelajaran konvensional.

Pertanyaan selanjutnya adalah apa yang kita pelajari. Pertanyaan-pertanyaan seperti apakah kurikulum telah sesuai dengan kebutuhan siswa dan apakah kurikulum telah dirancang untuk menyiapkan siswa untuk hidup dan bekerja pada masa yang akan datang perlu sekali lagi dilontarkan. Perkembangan TI yang sangat pesat harus dipertimbangkan dalam menjawab pertanyaanpertanyaan ini. Menurut Resnick (2002), selain TI akan sangat mewarnai masa depan, TI juga mengubah tidak hanya terhadap apa yang seharusnya dipelajari oleh siswa, tetapi juga apa yang dapat dipelajari. Sangat mungkin banyak hal yang seharusnya atau dapat dipelajari siswa tetapi tidak bias dimasukkan ke dalam kurikulum karena "ruang" yang terbatas atau kompleksitas yang tinggi dalam mengajarkannya. Terkait dengan ini, paradigma pembelajaran yang 
sebelumnya mengandaikan bahwa sumberdaya pembelajaran hanya terbatas pada materi di kelas dan buku harus diubah. Hadirnya TI, terutama Internet, telah menyediakan sumberdaya pembelajaran yang tidak terbatas. Sudah saatnya learning society dikampanyekan sebagai salah satu manifestasi kesadaran semangat pembelajaran sepanjang hayat (long-life learning).

Kapan dan dimana belajar dilakukan adalah pertanyaan ketiga yang perlu dipikirkan kembali jawabannya. Apakah harus dalam ruangan kelas dalam waktu tertentu atau tidak terbatas ruang dan waktu? Model pembelajaran tatapmuka yang banyak membatasi waktu dan tempat belajar. Sebagai komplemen (atau substitusl), teknologi elearning hadir untuk memberikan kebebasan kepada siswa dalam memilih tempat, waktu, dan ritme belejar (Kirkpatrick, 2004). Interaksi yang difasilitasi oleh TI ini dapat terjadi secara sinkron (pada waktu yang sama) maupun asinkron (dalam waktu yang berbeda).

Banyak kritik dialamatkan kepada penggunaan internet sebagai edukasi yang dianggap tidak membertimbangkan aspek pedagogis. Karenanya, menurut Institute for Higher Education Policy, Amerika (dalam Govindasamy, 2002) terdapat tujuh parameter yang perlu diperhatikan dalam menerapkan e-learning yang mempertimbangkan prinsip-prinsip pedagogis, yaitu: (1) institutional support, (2) course development, (3) teaching and learning, (4) course structure; (5) student support, (6) faculty support, dan (7) evaluation and assessment.

Karenanya, dalam bahasa yang lain, Soekartawi (2003) mengidentifikasi bahwa keberhasilan implementasi e-learning sangat tergantung kepada penilaian apakah: (a) e-learning itu sudah menjadikan suatu kebutuhan; (b) tersedianya infrastruktur pendukung seperti telepon dan listrik (c). tersedianya fasilitas jaringan internet dan koneksi Internet; (d) software pembelajaran (learning management system); kemampuan dan ketrampilan orang yang mengoperasikannya; dan (f) kebijakan yang mendukung pelaksanaan program e-learning.

Dalam konteks yang lebih luas, yaitu dalam manajemen dunia pendidikan, berdasar studi tentang tujuan pemanfaatan TI di dunia pendidikan terkemuka di Amerika, 
Alavi dan Gallupe (2003) menemukan beberapa tujuan pemanfaatan TI, yaitu memperbaiki competitive positioning, (2) meningkatkan brand image; (3) meningkatkan kualitas pembelajaran dan pengajaran; (4) meningkatkan kepuasan siswa; (5) meningkatkan pendapatan; (6) memperluas basis siswa; (7) meningkatkan kualitas pelayanan; (8) mengurangi biaya operasi; dan (9) mengembangkan produk dan layanan baru. Karenanya, tidak mengherankan jika saat ini banyak perguruan tinggi di Indonesia yang berlomba-lomba berinvestasi dalam bidang TI untuk memenangkan persaingan yang semakin ketat.

Dengan demikian sudah seharusnya menjadikan teknologi informasi dan komunikasi sebagai kebutuhan dalam "identifikasi diri" para mahasiswa agar menjadi modern dan mampu menghadapi globalisasi. Dan menjadi tugas guru/dosen untuk menyiapkan peserta didik "melek" teknologi sehingga mereka dapat bersaing dan memenangkan persaingan dalam globalisasi.

\section{PENUTUP}

Perkembangan Teknologi Infomnasi yang mampu mengolah, mengemas dan menampilkan serta menyebarkan informasi pembelajaran baik dalam medium audio, visual, audio visual bahkan mufti rnedia dewasa ini telah mampu mewujudkan apa yang disebut dengan Virtual Learning. Konsep ini berkembang, sehingga mampu mengemas kondisi dan realitas pembelajaran sebelumnya menjadi lebih menarik dan memberikan pengkondisian secara adaptif pada si pembelajaran dimanapun mereka berada. Upaya ke arah tersebut memang banyak dicontohkan dengan munculnya konsep e-leaming. Di mana secara realitas bahwa pembelajaran itu tidak sulit walaupun dibatasi olah ruang dan jarak, yani tidak mungkin jika dilakukan secara nature, akan tetapi justru realitas yang diharapkan ini mampu diwujudkan melalui konsep e-leaming ini. Pada bagian ini penulis akan mendeskripsikan realitas pembelajaran yang ditujukan pada hakikat informasi sebagai sumber belajar sebagai produk teknologi informasi. Di mana informasi disini dapat diklasifikasikan menjadi informasi elektronik, karena mereka akan ditampilkan melali elektronik pembelajaran. 
Kita semua sudah mulai familier dengan konsep dan realitas serta implementasi bahkan sampai dengan tahap pengembangan eleaming , maka realitas pernbelajaran ini pada dasarnya berjalan di atas jembatan atau medium yang kita kenal dengan Teknologi iformasi. Sampai saat ini pemanfaatan informasi melalui teknologi elektronik dalam proses pembelajaran tidak hanya berlaku bagi individu (khususnys peserta didik), tetapi juga bagaimana sender dalam hal ini pendidik mampu memanfaatkannnya untuk kepentingan pengemasan infomnasi belajarnya. Dalam posisi kita sebagai pendidik, dapat memanfaatkan fasilitas ini untuk kepentingan memperkaya kemampuan mengajar sehari-hari.

\section{DAFTAR PUSTAKA}

A. Jatmiko Wibowo, Fandy Tjiptono, "Pendidikan Berbasis Kompetensl', Penerbitan Universitas Atma Jaya, Yogyakarta, 2002.

Alavi, M., dan Gallupe, R. B. (2003). Using Information Technology in Learning: Case Studies in Business and Management Education Programs. Academy of Management Learning and Education, 2(2), 139-153.

Baisoetii. (1998). Komputer dan Pendidikan. Yogyakarta.

Govindasamy, T. (2002). Successful Implementation of e-Learning: Pedagogical Considerations. Internet and Higher Education, 4, 287-299.

H. A. R. Tilaar, MScEd., "Manajemen Pendidikan Nasional: Kajian Pendidikan Masa Depan", PT. Remaja Rosdakarya, Bandung, 2004.

Hamalik, Oemar (1986). Media Pendidikan.Bandung : Penerbit Alumni

Horton, William. 2000. Designing Web Based Training, John Wiley \& Son Inc. USA.

Johnson W. And Johnson R.T. (1989). Effect of Cooperative and Individualistic Learning Experiences on Iterethnic Interaction Jurnal of Educational Psychologi Vol 73.

Kar Tin, L. (2001), Information Technology in Teacher Education, Published in the Asia Fasific.

Kirkpatrick, D. (2001) Who Owns the Curriculum? Dalam Brook, B., dan .Gilding, A. The Ethics and Equity of e-Learning in Higher Education. Melbourne: 
Equity and Social Justice, Victoria University, 41-48.

Martinus Yamin, MPd., "Strategi Pembelajaran Berbasis

Kompetensl', Gaung Persada

Press, Jakarta, 2003.

Natawidjaja, Rochman. 1982.

Pembaharuan dalam Metode

Pengajaran. Jakarta:

Depdikbud.

Oetomo, B.S.D dan Priyogutomo, Jarot. 2004. Kajian Terhadap Model e-Media dalamPembangunan Sistem eEducation, Makalah Seminar Nasional Informatika 2004 di Universitas Ahmad Dahlan Yogyakarta pada 21 Februari 2004.

Pannen, P. (2005). Pemanfaatan ICT dalam Pembelajaran. Presentasi pada Seminar Sun Commitment in Education and Research Industry, Jakarta, 29 Juni.

Resnick, M. (2002). Rethinking Learning in the Digital Age. Dalam Porter, M. E.,

Rossett, Allison, 2002. The ASTD ELearning Handbook, McGrawHill Companies Inc, New York, USA.

Sachs, J. D., dan McArthur, J. W. The Global Information
Technology Report 2001-2002:

Readiness for the Networked World.

Sadiman, Arif, dkk. (1986). Media

Pendidikan,

Pengertian,

pengembangan

dan

pemanfaatannya. Jakarta :

Rajawali Press.

Smart School Project Team, "The Smart School: An MSC Flagship Application", Government of Malaysia, 1997.

Soekartawi, 2003, e-Learning di Indonesia dan Prospeknya di Masa Mendatang, Makalah Seminar Nasional 'e-Learning perlu e-Library' di Universitas Petra Surabaya pada 3 Februari 2003.

Suleiman, A.Hamzah. (1985). Media Audio-Visual. Jakarta : Penerbit Gramedia

Surendro, Kridanto. 2004. Pengembangan Aplikasi Learning Content Management System untukMendukung Proses Pembelajaran Jaraj Jauh. Makalah Seminar Nasional Informarika 2004 di Universitas Ahmad Dahlan Yogyakarta pada 21 Februari 2004.

Syukur, Fatah, 2005. Teknologi Pendidikan. Semarang: Rasail. 
Undang-undang Republik Indonesia Nomor 20 Tahun 2003 Teantang SISTEM PENDIDIKAN NASIONAL.

Utomo, Junaidi. 2001. Dampak Internet Terhadap Pendidikan : Transformasi atau Evolusi,
Wahid Fathul. Peran Teknologi Informasi Dalam Modernisasipendidikan Bangsa. http://fathulwahid.staff.uii.ac.id / diakses tanggal 2 Januari 2011. 